九州大学学術情報リポジトリ

Kyushu University Institutional Repository

\title{
Morphological Change of Volcanic Mountain Slope by Gully Erosion of Pyroclastic Flow Units at Mt. Merapi in Indonesia
}

Nurdin, Muhammad

Soil and Water Conservation Laboratory, Faculty of Agriculture, Kyushu University

Marutani, Tomomi

Soil and Water Conservation Laboratory, Faculty of Agriculture, Kyushu University

https://doi.org/10.5109/24027

出版情報：九州大学大学院農学研究院紀要. 37 (3/4)，pp.341-347，1993-03. Kyushu University バージョン：

権利関係 : 


\title{
Morphological Change of Volcanic Mountain Slope by Gully Erosion of Pyroclastic Flow Units at $\mathrm{Mt}$. M erapi in Indonesia
}

\section{Muhammad Nurdin. and Tomomi Marutani}

Soil and Water Conservation Laboratory, Faculty of Agriculture, Kyushu University 46-03, Fukuoka 812, Japan

(Received December 15, 1992)

\begin{abstract}
A purpose of this paper is to clear the process of morphological change of volcanic mountain slope by gully erosion of pyroclastic flow units. Width and depth of gully channel were measured as the differentials of present contour lines and restore contour lines in each quadrate area cut by $1 \mathrm{~km}$ mesh. These values show the development rate of width and depth of gully channel. Results were as follows. (1) The process of morphological change by gully erosion developed very fast just after burying by pyroclastic flow units, but the development rate was tend to decrease along an exponential curve. (2) According to develop the gully erosion upward, it seems to be occur junction of gully channels and the junction leads to scramble for channel basin at mountain slope. (3) Burying of gully channels by pyroclastic flow units caused not only acceleration of erosion after interruption of erosion but also scramble for channel basin. These process caused the vast amount of sediment from gully channels and many flood disasters.
\end{abstract}

\section{INTRODUCTION}

Indonesian archipelago has more than 128 active volcanoes. One of them is Mt. Merapi located in Java island. The summit of her is the border between two provinces, Yogyakarta special region and central Java province. People living around Mt. Merapi has suffered terribly from numerous volcanic disasters. These disasters are caused by the vast amount of volcanic products, which are accumulated on mountain slope with pyroclastic flows.

At Mt. Merapi, 64 times volcanic eruptions for recent 1000 years were on record. Most of them thickly covered the mountain slope of eastern to western by pyroclastic flow units. Although pyroclastic flow has not occurred since 1986, the danger of large -scale eruption keep on today. At the same time, morphological changes by gully erosion of pyroclastic flow units are occurring rapidly with flood disasters.

A purpose of this study is to clear the process of morphological change by gully erosion of pyroclastic flow units at Mt. Merapi. We intend to discuss the scramble for channel basin based on the difference of velocity of gully erosions.

\section{TOPOGRAPHY AND GEOLOGY}

Altitude of Mt. Merapi is $2911 \mathrm{~m}$ above sea level and longitudinal profile appears to be a conical volcano as a whole. Main rivers flowing dawn from Mt. Merapi are; at southwest side (Progo river basin): K. Pabelan, K. Blongkeng, K. Putih, K. Bebeng 
and K. Krasak, at south side (Opak river basin): K. Boyong, K. Kuning and K. Gendol, at southeast side (Denken river basin): K. Woro, K. Bramba and K. Pusur.

The profile of Mt. Merapi can be classified into;

(1) The upper slope area above $2000 \mathrm{~m}$ : In the summit area, which is formed from volcanic products and lava, gradient is very steep more than 35 degree, because of the constant eruptions and addition of new volcanic products. There is no vegetation. At present time the crater opens to southwest side and almost all of the products flow into southwest side of mountain.

(2) The middle slope area from $500 \mathrm{~m}$ to $2000 \mathrm{~m}$ : In this area, nuee ardante and lahar have flowed down into the gullies and changed the channel courses during major eruptions. Since the volcanic activity subsided, volcanic products have been eroded by hard rainfall and deep gully channels have been quickly formed.

(3) The lower slope area under $500 \mathrm{~m}$ : This area is relatively flat, gently sloping surface with a gradient of less than 3 degree.

Geology in the area of Mt. Merapi can be classified into following five groups, recent volcanic products, terrace and other unconsolidated deposits, young merapi volcanic products, old Merapi products and base rock. Recent volcanic products consists mainly of lava flows and pyroclastic flow units by eruption since 1888 and lahar that has occurred since 1930.

\section{METHODS}

There are clearly two seasons in Indonesia, dry and rainy seasons. Rainy season include two to four rain showers in a day, and dry season include little rain shower. In dry season, soil avalanches occur from both gully banks. On the other hand, the deposit buring gully is transported with flood caused by rain shower in rainy season. By repeating of this operation, gully erosion in the upper part of volcanic mountain becomes larger and deeper.

Mt. Merapi contains a old volcano in its northeastern slope and joins with Mt. Merbabu volcano in its northern slope, but forms a conical shape in its southwestern slope. The process of gully erosion can be shown as the windings of contour lines according to altitude and direction of volcanic mountain.

Figure 1 shows a contour map upward of 500 meters in altitude at southwestern slope of Mt. Merapi. The windings of contour lines show erosion volume of mountain slope since the age of conical shape formation. Because the contour lines of young conical volcano are described by smooth convex lines without erosion.

Figure 2 shows the measuring method. Shapes of gully channels were measured in a quadrate area cut by $1 \mathrm{~km}$ mesh in the contour map. Width and depth of gully channel were measured from different stream lines of gully channels, because of extracting at same stream. These values ( $K$ value) show the development rate of width and depth of gully channels.

\section{RESULTS AND DISCUSSION}

1. Burying of gully channels by pyroclastic flow units and its erosion process Figure 3 shows the distribution of $\mathbf{K}$ value in the area of pyroclastic flow units 


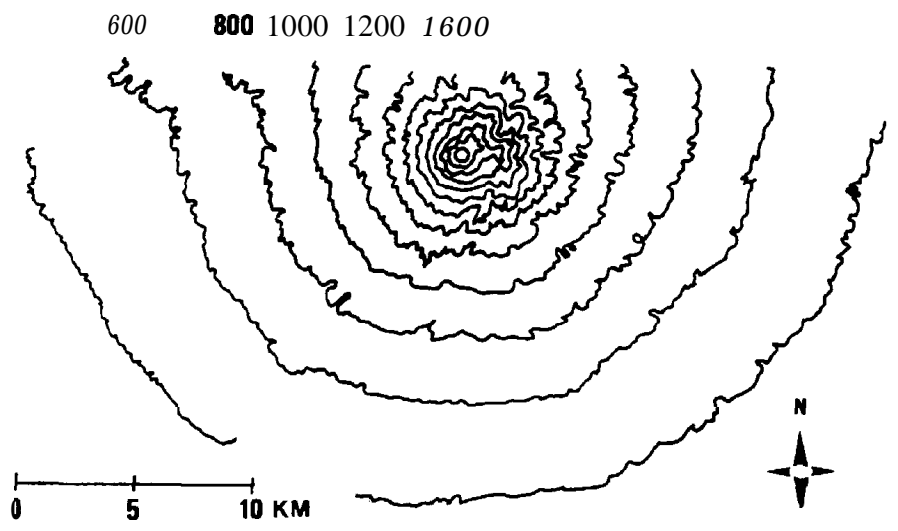

Fig. 1. Geomorphology of Mt. Merapi Southern Slope.

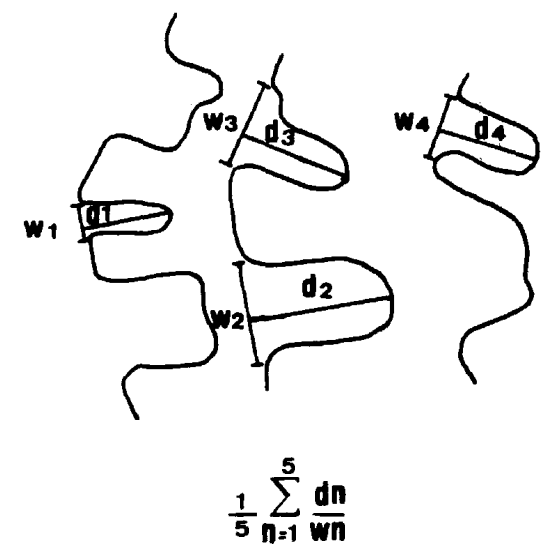

Fig. 2. Measuring method of $\mathrm{K}$ value about contour line.

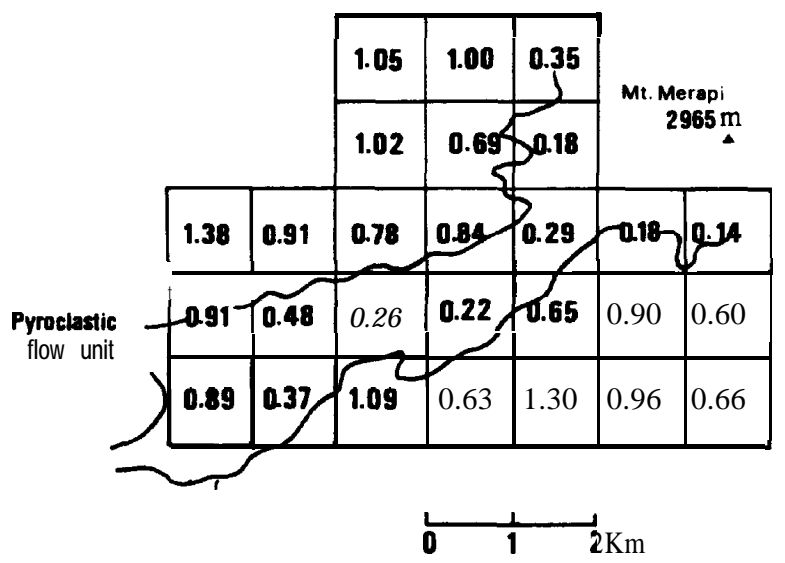

Fig. 3. Distribution of $\mathrm{K}$ value around the crater of Mt. Merapi. 
occurred in 1930, 1969, 1972 and 1984 (Marutani et al., 1992). The flow units covered around the crater as well as flow out to west-southwest side of crater. Near the crater, the $\mathrm{K}$ value is very small, for example $0.14,0.35$, and that increases from 0.29 to 0.91 according to distance from the crater. But at quadrats of 4 or $5 \mathrm{~km}$ away from crater, the $\mathrm{K}$ value is similar to that around the crater covering with pyroclastic flow units.

At Mt. Merapi, there have been 64 volcanic eruptions recorded in past 1000 years, and recently those in 1930, 1969, 1972, 1984 produced a vast amount of pyroclastic flow units. Therefore, it can be said that the relationship between width and depth of gully channels is changed not only by scour of pyroclastic flow units but also by deposit of them. Figure 4 shows the distribution of pyroclastic flow units occurred in 1930, 1969, 1972, 1984 (Kemmerling, 1931; Van Bemmelen, 1943; Republic of Indonesia, 1984). Pyroclastic flows in 1930 and 1972 accumulated toward K. Pabelan and K. Putih and their volumes were relatively small. On the other hand, pyroclastic flows in 1969 and 1984 accumulated toward K. Putih to K. Bebeng and their volumes were quite large as reaching to the area of 500 meters in altitude.

We can find out in fig. 4 that there are some places where pyroclastic flow have never accumulated and other places where they have accumulated several times in past 60 years. Taking this pyroclastic flows record into account, the difference of the $\mathrm{K}$ value for each place was analyzed. The number of times, pyroclastic flows have accumulated in the past 60 years $(1930-1960)$, were read out in each quadrats. This is taken as a frequency of pyroclastic flow units for 60 years.

Figure 5 shows the relationship between frequency of pyroclastic flow units and $\mathrm{K}$ value. The left risen tendency can be recognized even though each points disperse. The tendency indicates that development process of gully channels since burying by pyroclastic flow units was caused more vertically in channel than horizontally in channel. Especially at the area of high frequency in burying by pyroclastic flow units, the development was delayed.

The black dots is included in the area of newest pyroclastic flow unit in 1984 . Most of white dots without the accumulation of pyroclastic flow units for past 60 years are distributed around $1.0(0.60-1.30)$, Black dots are distributed around $0.25(0.14-0.48)$.

Based on the estimation of burying gully channels by pyroclastic flow units at 1984 , it was considered as follows. Although $\mathrm{K}$ value changed from 0 to 0.25 for six years since 1984 to 1990 , it has changed from 0 to 1.0 for a few hundred years before 1984. The result indicates that the process of morphological change by gully erosion develops very fast just after burying by pyroclasyic flow units, but the rate of the development is tend to decrease along an exponential curve.

2. Scramble for channel basin in pyroclastic flow units

It is cleared that development of gully erosion upward is caused by extension of channels. According to develop the gully erosion upward, it seems to occur the junction of gully channels. Because the conical shape of volcanic mountain causes geometrically the increment of probability of junction with drawing near the apex of cone. Junction of channels lead to scramble for channel basin at mountain slope.

Figure 6 shows the process of scramble for channel basin in pyroclastic flow units in 1969 and 1984. At the mountain slope after pyroclastic flow in 1969, two gully 


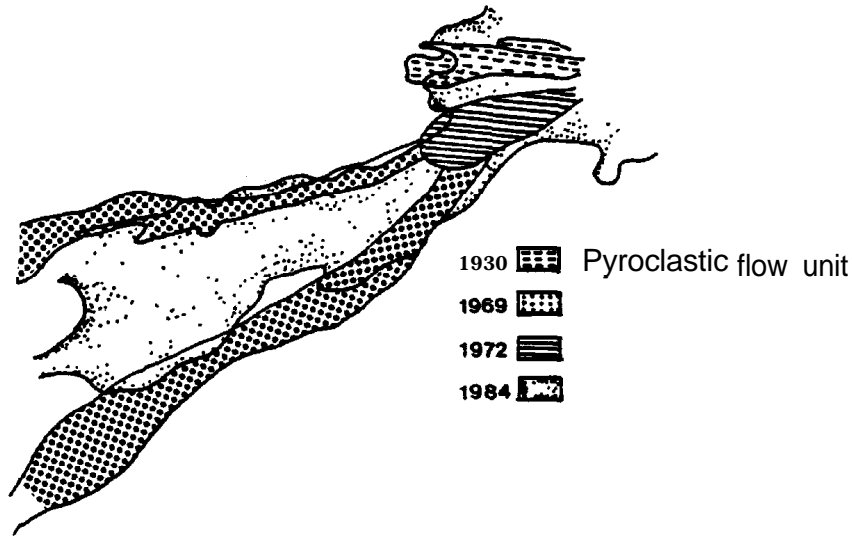

Fig. 4. Distribution of pyroclastic flow unit s (from 1930 to 1984) around the crater of Mt. Merapi.

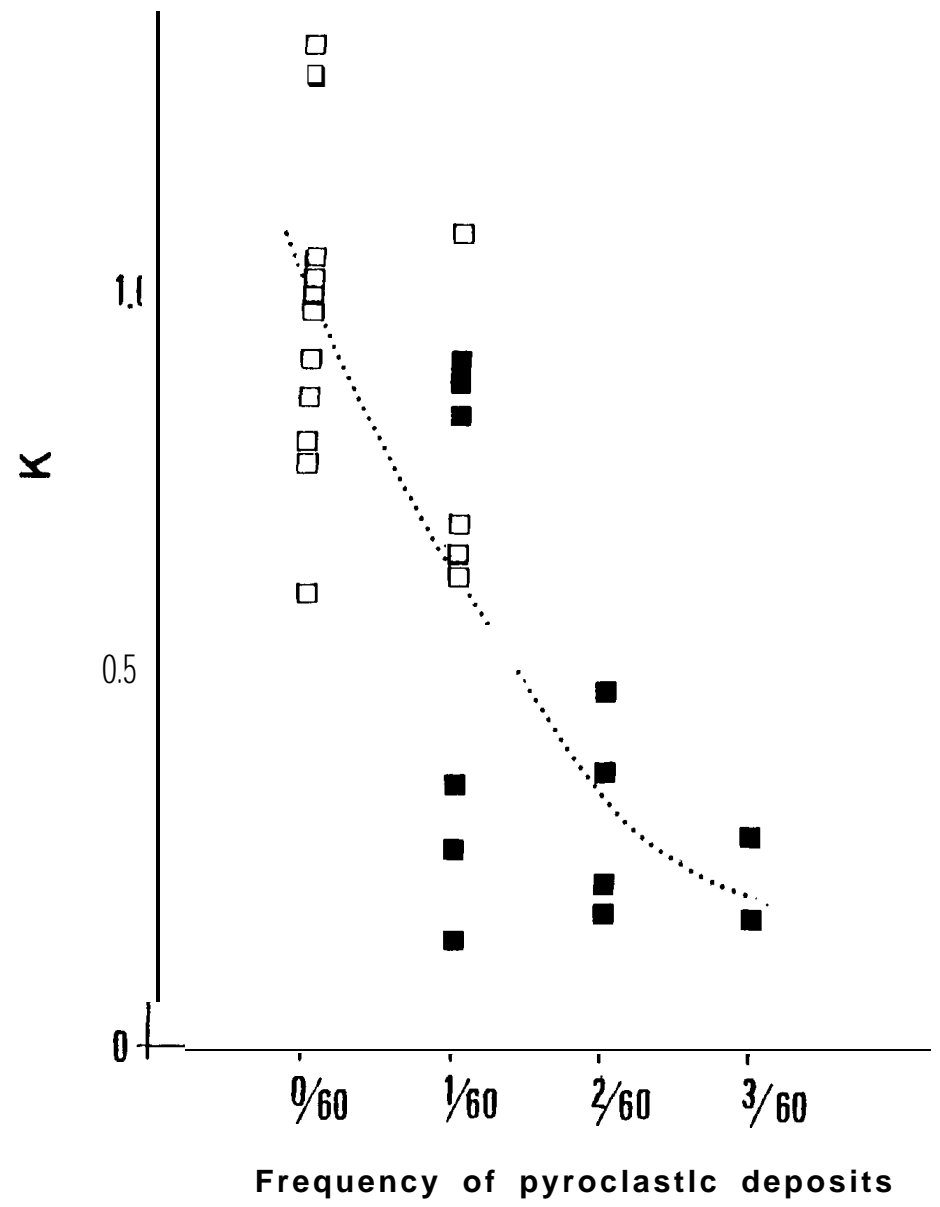

Fig. 5. Relationship between frequency of pyroclastic flow units and $\mathbf{K}$ value ( $\mathbf{Q}$ : by pyroclastic flow unit 1984). 


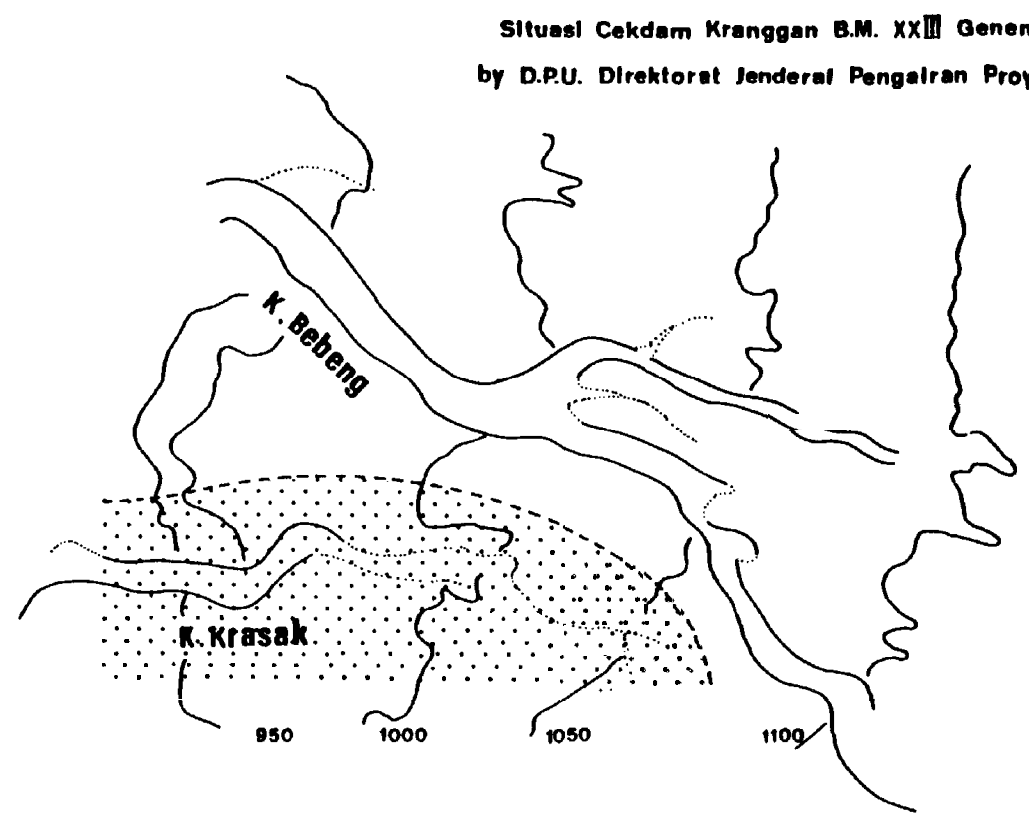

F-6

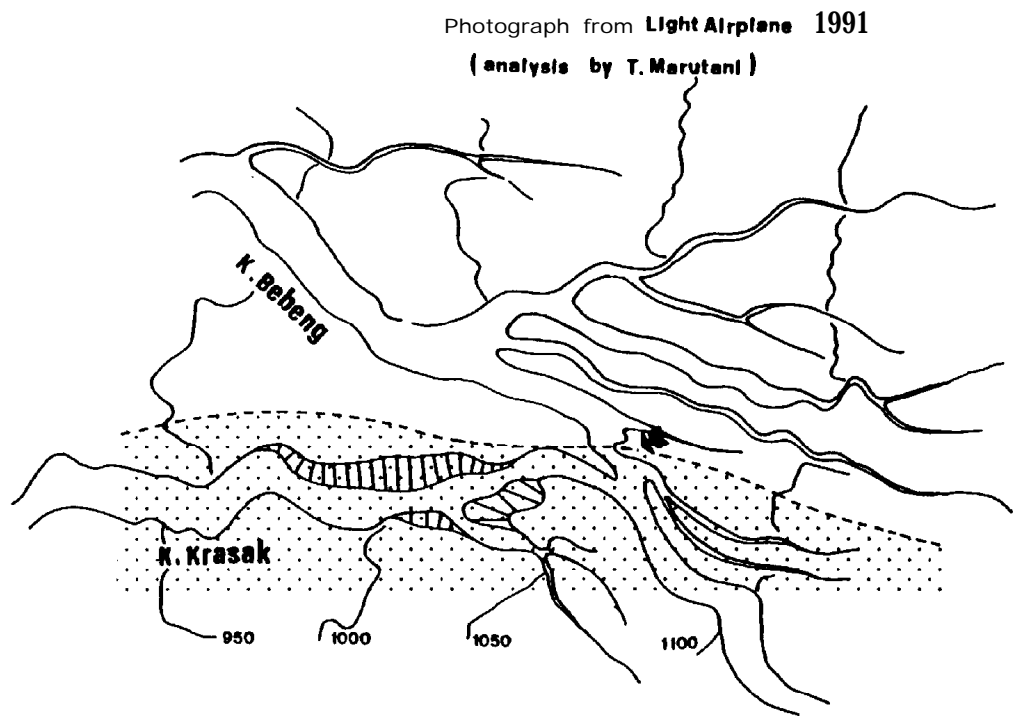

Fig. 6. Process of scramble for channel basin in pyroclastic flow units in 1969 and 1984. 
channels, K. Bebeng and K. Krasak, extended at 950-1000 $\mathrm{m}$ in altitude. But after pyroclastic flow in 1984, one of them, K.Krasak, extended rapidly upward and made a junction at $1050 \mathrm{~m}$ in altitude. Since the joining of $\mathrm{K}$. Krasak and K. Bebeng, the channel basin of $\mathrm{K}$. Krasak has extended its area and that of $\mathrm{K}$. Bebeng has contracted its area.

Now we define the temporary process to stop the development of gully erosion with decreasing the sediment productivity as interruption of erosion and the process to start the development of gully erosion with increasing the sediment porductivity as acceleration of erosion more than before interruption (Marutani et al., 1993). Based on these definition, the burying of gully channels by pyroclastic flow units caused not only acceleration of erosion after interruption of erosion but also scramble for channel basin. These process cause the change of sediment from gully channel and flood disasters at another region.

\section{ACKNOWLEDGEMENTS}

We are grateful to Prof. Dr. S. Kobashi and Assoc. Prof. Dr. Y. Fukushima of Kyoto University and Mr. T. Hirozumi and Mr. S. Agus of Volcanic Sabo Technical Centre for giving a chance of investigation at Mt. Merapi, and Prof. Dr. K. Takeshita of Kyushu University for fruitful suggestions.

\section{REFERENCES}

Kemmerling G. L. L. 1931 De west-helling van G. Merapi. De Ingenieur. Kon. Ned. Aardr. Gen. Kaart No.5

Marutani T., M. Nurdin and S. Shigyou 1993 Development of gully channels on the slope of Mt. Merapi volcano. Bull. Kyushu Univ. For., 68: 1-13

Marutani T., M. Nurdin and S. Shigyou 1992 Geomorphological process of gully erosion of pyroclastic flow unit at Mt. Merapi in Indonesia. Western Regional Report of Japan Group for the Study of Natural Disaster, No. 13: 65-69

Republic of Indonesia 1984 Master plan for land erosion and volcanic debris control in the area of Mt. Merapi.

Van Bemmelen R. W. 1943 Volcano-tectonic sketchmap of Mt. Merapi (Central Java). 